\title{
KETERAMPILAN BERMAIN SEPAKTAKRAW ATLET PELAJAR DIY
}

\author{
THE ABILITY OF PLAYING SEPAKTAKRAW \\ WITHIN THE STUDENT ATHLETES OF THE SPECIAL REGION OF YOGYAKARTA
}

\author{
Hubertus Purno Hananto, Hari Amirullah Rachman \\ PPs UNY, Universitas Negeri Yogyakarta \\ huberthananto@yahoo.co.id, -
}

\begin{abstract}
Abstrak
Penelitian ini secara umum bertujuan untuk mengetahui pengaruh kemampuan koordinasi dan metode latihan terhadap keterampilan sepaksila atlet sepaktakraw pelajar DIY. Secara spesifik untuk mengetahui: (1) perbedaan keterampilan sepaksila ditinjau kemampuan koordinasi; (2) perbedaan keterampilan sepaksila ditinjau metode latihan; (3) ada tidaknya interaksi antara kemampuan koordinasi dan metode latihan terhadap keterampilan sepaksila pada atlet sepaktakraw pelajar DIY. Penelitian ini menggunakan metode eksperimen, dengan pendekatan faktorial $2 \times 2$ desain blok. Populasi penelitian ini adalah seluruh atlet sepaktakraw pelajar DIY, dan sampel diambil sejumlah 28 orang dengan teknik purposive sampling. Hasil penelitian: (1) ada perbedaan yang signifikan keterampilan sepaksila ditinjau kemampuan koordinasi (2) ada perbedaan yang signifikan keterampilan sepaksila ditinjau metode latihan dan (3) ada interaksi yang signifikan antara kemampuan koordinasi dan metode latihan terhadap keterampilan sepaksila pada atlet sepaktakraw pelajar DIY.
\end{abstract}

Kata Kunci: Keterampilan, Sepaksila, Kemampuan Koordinasi, Metode Latihan, Metode Berpasangan, Metode Bertiga.

\begin{abstract}
This study aims to investigate the effect of the coordination capabilities and training methods on the sepaksila skills of sepaktakraw student athletes in Yogyakarta Special Territiry (YST), especially to find out; (1) the difference in the sepaksila skills in terms of the coordination capabilities; (2) the difference in the sepaksila skills in terms of the training methods; (3) the interaction between the coordination capabilities and the training methods on the sepaksila skills of sepak satkraw student athletes in YST. This study employed the experimental method with the $2 \times 2$ factorial block design. The research population comprised all sepaktakraw student athletes in YST and the sampel, consisting of 28 athletes, was selected using the purposive sampling technique. The conclusions of the study are as follows. (1) There is a significant defference in the sepaksila skills in terms of the coordination capabilities; (2) There is a significant difference in the sepaksila skills in terms of the training methods; (3) There is a significant interaction between the coordination capabilities ant the training methods on the sepaksila skills among the sepaktakraw student athletes in YST.
\end{abstract}

Keywords: Skills, Sepaksila, Coordination Capabilities,Training Method,Pair Method, Triple Method. 


\section{Pendahuluan}

Sepaktakraw merupakan salah satu cabang olahraga yang tidak bisa dipungkiri masih belum terlalu populer di Indonesia. Sepaktakraw masih dipandang sebelah mata oleh masyarakat umum, padahal olahraga tersebut merupakan salah satu cabang olahraga asli Indonesia yang disebut sepakraga, yaitu permainan anak negeri di daerah yang menggunakan bola yang terbuat dari rotan (Yusuf, 2001, p.3). Sepaktakraw mempunyai prospek yang cerah apabila dilakukan pembinaan secara baik dan profesional di seluruh daerah-daerah dan akan sangat mungkin menjadi olahraga yang populer di Indonesia bahkan bisa mendunia. Faktualnya sepaktakraw merupakan olahraga nenek moyang dahulu yang sudah sepantasnya untuk dilestarikan.

Kekuatan sepaktakraw di tingkat asia maupun dunia untuk saat ini masih didominasi Thailand. Prestasi tersebut berkat menajemen olahraga yang terprogram secara efektif, kontinyu serta sistematis. Bagaimana permasalahan dengan sepaktakraw Indonesia? Sebenarnya Indonesia juga mempunyai potensi yang besar untuk menunjukkan prestasi sepaktakraw di kancah internasional. Dilihat dari kualitas tidak jauh berbeda, hanya pengelolaan menajemen yang belum terprogram secara sistematis dan efektif yang menyebabkan atlet belum bisa secara maksimal dan koheren dalam menghasilkan prestasi.

Seorang atlet akan mampu mengembangkan potensinya secara optimal apabila memenuhi faktor-faktor berikut ini: karakteristik fisik, yaitu komponen penting yang harus dimiliki sebagai penunjang penampilan (kapasitas fisik). Penguasaan teknik secara benar yang diperlukan cabang olahraga tertentu dapat dikembangkan (biomekanika). Tingkat kebugaran secara spesifik untuk aktivitas olahraga tertentu harus dicapai (kapasitas fisiologi). Faktor-faktor psikologis yang memungkinkan atlet berhasil dalam suatu kompetisi perlu dikembangkan dan dipertahankan (menaikkan kondisi psikologis), etika kerja termasuk sikap yang tepat dalam latihan harus ditampilkan dan kesempatan untuk berkompetisi dengan atlet lain yang setara atau tingkat yang lebih tinggi harus tersedia.

Dilihat dari karakteristiknya, sepaktakraw merupakan perpaduan dari berberapa jenis olahraga. Bila diamati dengan jeli gerakan dalam permainan sepaktakraw, maka akan dijumpai adanya berbagai unsur seperti gerakan se- nam yaitu ketika dibutuhkan fleksibelitas saat gerakan salto untuk melakukan smash, bulutangkis yaitu bentuk dan ukuran lapangan yang sama, sepakbola yaitu saat mengontrol bola boleh menggunakan seluruh bagian badan kecuali tangan, dalam bolavoli yaitu bentuk permainan yang memvoli menggunakan seluruh bagian tubuh kecuali tangan yang tidak diperbolehkan serta akrobatik yaitu saat salto di udara sambil menendang bola dan segera kembali ke posisi berdiri.

Unsur-unsur tersebut dapat dilihat ketika seorang spikers (apit kiri/apit kanan) yang sedang melakukan smash sambil melompat dan bersalto, atau seorang tekong yang melakukan servis keras menggunakan punggung kaki sambil membelakangi net, serta seorang puder (apit kanan/apit kiri) sedang mengontrol bola dengan paha atau dada, menimang bola menggunakan punggung kaki, dan melambungkan umpan kepada si spikers. Kemampuan penguasaan teknik-teknik di atas haruslah distimulus dengan latihan yang efektif, intensif dan sistematis agar dapat menghasilkan keterampilan yang mumpuni sebagai seorang pemain sepaktakraw yang benar-benar handal dan dapat mencapai prestasi maksimal (http://rapid4me.com/?n=15+sepak+takraw).

Setiap cabang olahraga harus menguasai teknik dasar terlebih dahulu agar bisa menjadi atlet yang berprestasi, seperti sepakbola harus menguasai keterampilan dasar dribbling, control, passing, dan shooting, juga dengan olahraga voli harus menguasai keterampilan dasar seperti passing, service dan smash. Tenis lapangan juga harus terlebih dahulu menguasai keterampilan dasar seperti teknik pukulan service, backhand, forehand dan smash.

Tuntutan agar dapat bermain sepaktakraw secara handal haruslah diimbangi dengan memiliki keterampilan yang baik. Kemampuan tersebut adalah keterampilan menguasai teknik dasar terlebih dahulu, karena dalam cabang olahraga apapun tanpa menguasai teknik dasar terlebih dahulu, dapat dipastikan tidak dapat menguasai olahraga tersebut dengan baik. Berlaku juga dalam sepaktakraw, tanpa menguasai teknik dasar sangat sulit bermain sepaktakraw secara mahir. Dalam permainan sepaktakraw ada berbagai macam teknik dasar yang harus dikuasai oleh pemain agar dapat bermain sepaktakraw secara terampil seperti kemampuan menimang (sepaksila), passing, servis (sepakmula), heading, smash dan block. Namun tidak berarti prestasi sepaktakraw hanya ditentukan 
oleh pemilik teknik dasar yang baik semata (Depdikbud, 2004, p.4).

Kemampuan koordinasi merupakan salah satu unsur penting yang mendukung pencapaian keterampilan motorik. Olahraga permainan hampir semuanya membutuhkan komponen biomotor koordinasi, yang merupakan kombinasi dari unsur kecepatan, ketepatan dan keseimbangan (Sukadiyanto, 2004, p.19). Koordinasi yang diperlukan dalam permainan Sepaktakraw adalah koordinasi mata-tangan-tungkai. Mata sebagai indra penglihatan merupakan salah satu yang menerima rangsang untuk diteruskan ke otak dan diproses dengan respon yang berbentuk gerakan. Respon yang terjadi adalah menyepak bola takraw sebagai perpanjangan dari kaki. Sedangkan tangan harus menyesuaikan irama gerakan kaki sebagai penyeimbang tubuh agar tetap stabil.

Komponen biomotor koordinasi merupakan salah satu faktor pendukung keberhasilan dalam permainan sepaktakraw. Koordinasi dalam permainan sepaktakraw mutlak diperlukan karena terdapat banyak gerakan-gerakan yang dilakukan harus dengan koordinasi yang baik. Sebagai contoh adalah ketika seorang tekong mengontrol bola hasil dari smash lawan yang berada jauh dari badan maka si tekong harus bergerak dengan cepat, tepat dan badan harus tetap stabil agar bola dapat terselamatkan (Darwis, 1995, p.21). Untuk dapat bermain sepaktakraw dengan baik, di samping harus memiliki kondisi fisik prima, keterampilan teknik dan taktik perlu dikuasai secara baik pula (Thamrin, 2006, p.5).

Pegaruh koordinasi terhadap keterampilan sepaksila dalam permainan sepaktakraw sangat dominan dan esensial. Hal tersebut dapat terlihat bila seseorang tidak mempunyai koordinasi yang baik, maka akan sulit baginya untuk dapat bermain sepaktakraw dengan terampil karena untuk mengejar bola yang datangnya secara eksplosif dan keras diperlukan kelincahan, kecepatan dan ketepatan yang baik. Pengaturan untuk mencapai gerakan yang efektif dapat mengurangi kelelahan dan dengan begitu juga berpengaruh terhadap upaya untuk mengoptimalisasikan kemampuan (Harsuki, 2012, p.20).

Permainan sepaktakraw merupakan salah satu cabang olahraga yang tergolong mempunyai tingkat kesulitan yang tinggi dalam penguasaan keterampilan gerak. Dibutuhkan latihan yang intensif dan penuh kerja keras serta kontinyu agar dapat bermain sepaktakraw secara terampil. Pelajar yang tertarik untuk mene- kuni sepaktakraw masih sangat minim dikarenakan melihat dari tingkat kesulitan permainan. Pelajar kebanyakan sudah merasa takut terlebih dahulu untuk sekedar mencoba bermain sepaktakraw dikarenakan bentuk permainan yang kelihatannya sulit.

Tingkat kesulitan dalam menguasai permainan sepaktakraw menjadi momok bagi kebanyakan pemula maupun pelajar untuk menekuni cabang olahraga ini. Metode latihan yang dijalankan pelatih di DIY hanyalah masih berdasarkan pengalaman saat menjadi atlet, bukan dari suatu metode yang telah teramati, tercatat dan terukur dan menerapkan pembinaan yang tepat, yang didukung oleh ilmu pengetahuan dan teknologi di bidang olahraga khususnya sepaktakraw.

Di DIY sendiri belum ada pelatih yang benar-benar mempunyai kapabilitas dan kualifikasi sebagai seorang pelatih yang spesialis di cabang olahraga sepaktakraw. Hal ini dibuktikan dengan belum adanya pelatih yang mempunyai sertifikat atau lisensi kepelatihan baik untuk level nasional maupun internasional sehingga untuk mengaplikasikan metode latihan masih menggunakan cara konvensional yaitu berdasarkan pengalaman pelatih saat menjadi atlet, bukan berdasarkan pada program latihan yang teramati, tercatat dan terukur, yang berimplikasi pada kurang efektif untuk peningkatan keterampilan permainan sepaktakraw yang menjadikan prestasi atlet yang ingin menekuni cabang olahraga ini kurang bisa berkembang secara maksimal.

Atlet sepaktakraw DIY sulit bersaing di level nasional apalagi internasional dikarenakan banyak faktor seperti: sinergi yang kurang efektif dan efisien dari para stakeholder PSTI (Persatuan Sepaktakraw Indonesia) DIY baik itu dalam sesama kepengurusan, antara pegurus dengan pelatih, antar-pengurus dengan atlet, belum adanya pelatih mumpuni yang bisa menstimulus atlet untuk mencapai potensi maksimal, minimnya kompetisi sebagai kesempatan untuk bertanding yang menyebabkan semangat untuk latihan atlet menjadi menurun serta sulitnya mencari sparing partner yang sepadan ataupun setingkat di atas di lingkup DIY yang bisa memacu terjadinya progresivitas atlet.

Faktualnya sudah sejak lama atlet DIY belum mampu lolos ke PON dikarenakan kalah bersaing dari daerah lain seperti Jawa Tengah yang didukung dengan pelatih dan program latihan yang efektif serta mempunyai PPLP dan PPLM sebagai penunjang proses latihan yang 
berkesinambungan dan progresif. Penelitian ini diharapkan menjadi salah satu referensi bagi atlet, guru, pakar olahraga, pelatih maupun stakeholder untuk meningkatkan kualitas dan kuantitas dalam permainan sepaktakraw. Semoga kelak di masa yang akan datang permainan sepaktakraw menjadi salah satu olahraga yang semakin digemari oleh masyarakat luas dan prestasi atlet DIY maupun atlet-atlet terbaik Indonesia mampu secara koheren berjaya di level internasional.

Berdasarkan pemaparan di atas maka dilakukan penelitian ini dengan harapan dapat memberikan jawaban atas permasalahan yang sering muncul dalam permainan sepaktakraw. Maka diharapkan penelitian ini dapat memberikan sumbangsih positif yang bermanfaat bagi peningkatan kualitas dan kuantitas sepaktakraw DIY khususnya dan Indonesia umumnya.

\section{Metode}

Metode yang digunakan dalam penelitian ini adalah eksperimen, yaitu faktorial $2 \times 2$ dengan desain blok. Penelitian ini untuk mengetahui ada tidaknya hubungan sebab akibat, yaitu dalam hal untuk mengetahui pengaruh metode latihan dan kemampuan koordinasi terhadap keterampilan sepaksila atlet pelajar DIY.

\section{Waktu dan Tempat Penelitian}

Tempat penelitian sepaktakraw ini berlokasi di GOR Prestasi, Jati Sriharjo Imogiri, Bantul, Yogyakarta. Waktu penelitian yaitu bulan Juni sampai dengan Juli 2012. Frekuensi perlakuan 3 kali dalam seminggu sebanyak 24 kali.

\section{Target/Subjek Penelitian}

Populasi adalah keseluruhan dari subjek penelitian, dalam penelitian ini populasi yang digunakan adalah atlet sepaktakraw pelajar DIY yang berjumlah 38 orang. Penelitian ini menggunakan penelitian sampel yaitu khusus atlet sepaktakraw pelajar DIY yang dipersiapkan untuk Pekan Olahraga Pelajar antar-Wilayah (POPWIL) pada bulan Oktober 2012 di Banten yang berjumlah 28 atlet.

Teknik pengambilan sampel dalam penelitian ini adalah purposive sampling di mana penentuan sampel berdasarkan pertimbangan tertentu yaitu memilih atlet yang mempunyai basic dalam cabang olahraga sepaktakraw agar tidak terjadi kesenjangan yang begitu jauh antara yang mempunyai keterampilan dan yang ti- dak mempunyai keterampilan dalam permainan sepaktakraw khususnya keterampilan sepaksila.

Prosedur

Dalam penelitian ini, kemampuan koordinasi dibedakan menjadi dua, yaitu kemampuan koordinasi tinggi dan kemampuan koordinasi rendah. Dalam menentukan sampel yang memiliki tingkat kemampuan koordinasi tinggi dan rendah, dilakukan dengan cara tes kemampuan koordinasi. Tes koordinasi yang dilakukan dengan cara melambungkan dan menyepakbola dari lingkaran tekong ke sasaran kotak-kotak yang berada di lapangan sebelah net yang sudah diberi besaran nilai tertentu pula. Dari hasil tes tersebut akan diperoleh data yang merupakan hasil dari sejumlah lambungan dan sepakan. Selanjutnya hasil lambungan sepakan bola dirangking dari atas adalah kelompok nilai yang besar dan yang ke bawah adalah kelompok nilai yang kecil. Setelah mendapatkan rangking nilai hasil tes koordinasi, maka diambil sejumlah $27 \%$ kelompok sampel yang memiliki nilai besar sebagai kelompok koordinasi tinggi dan sejumlah $27 \%$ kelompok sampel yang memiliki nilai kecil sebagai kelompok koordinasi rendah dari seluruh sampel di atas. Adapun urutan langkahlangkah pengambilan populasi dan sampel sebagai berikut: (1) Menentukan sampel secara Nonprobability Sampling yaitu Purposive Sampling dimana penentuan sampel berdasarkan pertimbangan tertentu (Sugiyono, 2011, p.85). Mendata pelajar antara SLTP dan SLTA yang mempunyai basic sepaktakraw. Pencatatan data pelajar yang mempunyai basic sepaktakraw. Alasan penentuan ini dikarenakan agar pada saat perlakuan tidak terlalu jauh kesenjangan antara yang memiliki keterampilan dan yang kurang memiliki keterampilan di dalam permainan sepaktakraw khususnya keterampilan sepaksila. Diperoleh 38 orang pelajar masuk dalam kriteria yang telah ditentukan; (2) Membagi kelompok metode latihan berpasangan dan metode latihan bertiga secara Nonprobability Sampling yaitu Purposive Sampling (sampel bertujuan, dengan maksud memilih khusus atlet yang mempunyai basic dalam olahraga sepaktakraw agar tidak terjadi kesenjangan yang terlalu jauh antara yang mempunyai kemampuan dan yang kurang mempunyai kemampuan) yaitu 20 orang kelompok latihan berpasangan dan 18 orang kelompok latihan bertiga; (3) Tahap berikutnya adalah mengadakan tes koordinasi yang merupakan variabel atribut dalam penelitian ini. Tes ini untuk menentukan kelompok yang memiliki 
koordinasi tinggi dan koordinasi rendah. Adapun cara yang dilakukan adalah dengan merangking hasil skor koordinasi setiap pelajar pada setiap kelompok perlakuan. Untuk menentukan tingkat koordinasi tinggi dan rendah menggunakan persentase, yaitu $27 \%$ untuk batas atas yang mewakili kelompok skor tinggi dan $27 \%$ yang mewakili kelompok skor rendah (Miller, 2002, p.68). Oleh karena itu, dari $27 \%$ kelompok tinggi dan $27 \%$ kelompok rendah benar-benar merupakan kelompok yang berbeda secara ekstrem (Sukadiyanto, 2004, p 131); (4) Diperoleh 28 orang sampel.

Teknik dan Instrumen Pengumpulan Data

\section{Teknik Pengumpulan Data}

Agar pegumpulan data sesuai dengan rencana, maka perlu disusun langkah-langkah yang valid. Skala pengukuran keterampilan sepaksila yang digunakan dalam penelitian ini adalah menggunakan satuan waktu (1 menit/60 detik) sehingga alat yang digunakan yaitu stopwatch. Dengan skala pengukuran ini, maka variabel yang diukur dengan instrumen ini dapat dinyatakan dalam bentuk angka sehingga lebih akurat, efisien dan komunikatif.

Penelitian ini menggunakan dua macam data yang harus dikumpulkan, yaitu: (1) data kemampuan koordinasi, dan (2) data keterampilan sepaksila. Data kemampuan koordinasi diambil sebelum pelaksanaan treatment dimaksudkan untuk mengelompokkan subjek yang memiliki kemampuan koordinasi tinggi dan yang memiliki kemampuan koordinasi rendah ke dalam setiap metode latihan, dan dikumpulkan dengan instrumen pengukuran kemampuan koordinasi yang dikembangkan oleh Husni Thamrin. Data keterampilan sepaksila, diambil saat pretest dan posttest, pengumpulan data menggunakan tes keterampilan sepaksila.

Setelah sejumlah 38 orang atlet terkumpul, tahap pertama mengadakan tes kemampuan koordinasi yang merupakan variabel atribut dalam penelitian ini. Tes awal ini dimaksudkan untuk menentukan kelompok yang memiliki koordinasi tinggi dan koordinasi rendah. Adapun cara yang digunakan dengan menyusun urutan (merangking) hasil skor tes koordinasi yang diperoleh atlet pada setiap kelompok perlakuan untuk menentukan tingkat kemampuan koordinasi tinggi dan rendah menggunakan persentase, yaitu $27 \%$ untuk batas atas yang mewakili kelompok skor tertinggi dan $27 \%$ batas ba- wah yang mewakili kelompok skor rendah untuk pembagian ke masing-masing kelompok.

\section{Instrumen Pengumpulan Data}

Dalam penelitian ini digunakan instrumen yang berupa alat yang dipakai untuk mengumpulkan data. Ada dua macam instrumen yang digunakan untuk mengumpulkan data, yaitu instrumen untuk kemampuan koordinasi dan instrumen untuk keterampilan sepaksila. Penelitian ini ingin mengetahui kemampuan koordinasi dan pengaruh metode latihan terhadap keterampilan sepaksila atlet sepaktakraw pelajar DIY. Instrumen pokok yang digunakan dalam pengambilan data yaitu:

PertamaTes Kemampuan Koordinasi, yaitu menyepak bola takraw dari lingkaran tekong diarahkan ke lapangan yang sudah diberi nilai. (1) Tujuannya untuk mengetahui tingkat koordinasi seseorang atlet dalam melakukan sepak mula dari 10 kali pelaksanaan. 2). Alat: (a) Alat tulis, (b) Bola takraw, (c) Lapangan, (d) Kapur tulis. 3).Petunjuk pelaksanaan: (a) Pemain menempati lingkaran tekong dalam lapangan sepaktakraw untuk melakukan sepakmula, (b) Setelah aba-aba "Ya", pemain melakukan sepakmula menggunakan 10 bola dan dihitung jumlah sesuai jatuhnya bola ke kotak poin yang bernilai berapa, (c). Diwajibkan menggunakan teknik sepaksila dalam melakukan sepakmula bukan teknik yang lainnya, (d) Usahakan agar bola jatuh di daerah skor yang tinggi. 4). Penilaian: Penilaian yang diberikan yaitu kemampuan melakukan sepak mula dari 10 kali pelaksanaan dan dari dua kali repetisi diambil jumlah yang terbaik (Thamrin, 2010, p 94).

Tabel 1. Norma Penilaian Sepakmula untuk Kemampuan Koordinasi.

\begin{tabular}{ccc}
\hline Kategori & Kode & Skor Baku \\
\hline Baik Sekali & A & 68 ke atas \\
Baik & B & $56-67$ \\
Sedang & C & $44-55$ \\
Kurang & D & $32-43$ \\
Kurang Sekali & E & 31 ke bawah \\
\hline
\end{tabular}

Keterampilan Sepaksila

Keterampilan sepaksila merupakan kemampuan dari seorang atlet untuk melakukan sepakan (menimang) bola menggunakan kaki bagian dalam sebanyak-banyaknya. (1) Tujuan: untuk mengetahui tingkat keterampilan seseorang pemain dalam melakukan sepaksila dalam satu menit (60 detik); (2) Alat: (a) Alat tulis, (b) Bola takraw, (c) Lapangan, (d) Stop 
watch; (3) Petunjuk pelaksanaan: (a) Pemain menempati lapangan sepaktakraw untuk melakukan sepaksila, (b) Setelah aba-aba "Ya", pemain melakukan sepaksila menggunakan satu bola (dihitung banyaknya dalam 60 detik) tanpa bola jatuh ke lantai dan dilakukan dua kali repetisi, (c) Diwajibkan menggunakan teknik sepaksila bukan teknik yang lainnya, (d) Usahakan agar bola selama mungkin tidak jatuh ke lantai; (4) Penilaian: Penilaian yang diberikan yaitu diambil jumlah yang terbanyak dari kemampuan melakukan sepaksila dalam satu menit dan dari dua kali repetisi diambil jumlah yang terbanyak (Thamrin, 2010, p 94).

Tabel 2. Norma Penilaian Keterampilan Sepaksila.

\begin{tabular}{ccc}
\hline Kategori & Kode & Skor Baku \\
\hline Baik Sekali & A & 68 ke atas \\
Baik & B & $56-67$ \\
Sedang & C & $44-55$ \\
Kurang & D & $32-43$ \\
Kurang Sekali & E & 31 ke bawah \\
\hline
\end{tabular}

\section{Hasil Penelitian dan Pembahasan}

Teknik pengumpulan data pada penelitian ini menggunakan dua macam tes, yaitu: (1) tes kemampuan koordinasi, dan (2) tes keterampilan sepaksila. Tes koordinasi dilaksanakan pada waktu sebelum perlakuan (treatment), guna mengelompokkan siswa menjadi dua kelompok, yaitu kelompok siswa dengan tingkat kemampuan koordinasi yang tinggi dan kelompok siswa dengan tingkat kemampuan koordinasi yang rendah. Masing-masing kelompok tersebut terdiri dari 14 siswa, selanjutnya dibagi lagi menjadi dua kelompok, yaitu: kelompok siswa yang akan diberi treatment latihan berpasangan dan kelompok siswa yang diberi treatment latihan bertiga sehingga jumlah kelompok pada penelitian ini adalah 4 kelompok siswa, terdiri dari: (1) koordinasi tinggi metode latihan berpasangan atau $\mathrm{A}_{1} \mathrm{~B}_{1}$, (2) koordinasi tinggi metode latihan bertiga atau $A_{1} B_{2}$, (3) koordinasi rendah metode latihan berpasangan atau $\mathrm{A}_{2} \mathrm{~B}_{1}$, dan (4) koordinasi rendah metode latihan bertiga atau $\mathrm{A}_{2} \mathrm{~B}_{2}$.

Adapun tes keterampilan sepaksila, yaitu keterampilan sepaksila merupakan kemampuan dari seorang pemain (atlet) untuk melakukan sepakan (menimang) bola menggunakan kaki bagian dalam sebanyak-banyaknya. Penilainya diambil dalam waktu satu menit (60 detik) berapa banyak melakukan sepaksila dan dari dua kali repetisi diambil jumlah yang terbanyak (terbaik).

Berikut ini disajikan analisis deskriptif dari hasil tes keterampilan sepaksila, berupa angka-angka tendensi sentral (mean, median, mode dan standard deviasi) dari masing-masing variabel penelitian, yaitu hasil tes awal (pretest), tes akhir (posttest), dan efektivitas peningkatan skor pada masing-masing kelompok perlakuan.

\section{Hasil Tes Awal (Pretest)}

Hasil tes awal keterampilan sepaksila pada atlet sepaktakraw pelajar DIY pada masing-masing kelompok perlakuan, secara ringkas disajikan pada tabel berikut ini.

Tabel 3. Statistik Deskriptif Keterampilan Awal Sepaksila pada Masing-masing Kelompok Perlakuan

\begin{tabular}{ccccc}
\hline Statistik & \multicolumn{2}{c}{$\begin{array}{c}\text { Kemampuan } \\
\text { Koordinasi } \\
\text { Tinggi } \\
\left(\mathbf{A}_{\mathbf{1}}\right)\end{array}$} & \multicolumn{2}{c}{$\begin{array}{c}\text { Kemampuan } \\
\text { Koordinasi } \\
\text { Rendah } \\
\left(\mathbf{A}_{\mathbf{2}}\right)\end{array}$} \\
\cline { 2 - 5 } & $\mathbf{B}_{\mathbf{1}}$ & $\mathbf{B}_{\mathbf{2}}$ & $\mathbf{B}_{\mathbf{1}}$ & $\mathbf{B}_{\mathbf{2}}$ \\
\hline Rerata (Mean) & 65,50 & 65,50 & 58,13 & 58,00 \\
Median & 67,00 & 65,00 & 59,00 & 59,00 \\
Mode & 67 & 65 & 60 & 60 \\
Standard & 1,195 & 2,588 & 3,271 & 3,286 \\
Deviasi & & & & \\
Variance & 1,429 & 6,700 & 10,696 & 10,800 \\
Range & 4 & 7 & 9 & 9 \\
Minimum & 64 & 62 & 53 & 52 \\
Maksimum & 68 & 69 & 62 & 61 \\
\hline Keranganyyy
\end{tabular}

Keterangan:

$\mathrm{A}_{1} \quad$ : Koordinasi Tinggi

$\mathrm{A}_{2} \quad$ : Koordinasi Rendah

$\mathrm{B}_{1} \quad$ : Latihan Berpasangan

$\mathrm{B}_{2} \quad$ : Latihan Bertiga

Berdasarkan tabel tersebut di atas, dapat dibuat histogram pencapaian rata-rata skor tes kemampuan awal sepaksila pada atlet sepaktakraw pelajar DIY sebagai berikut:

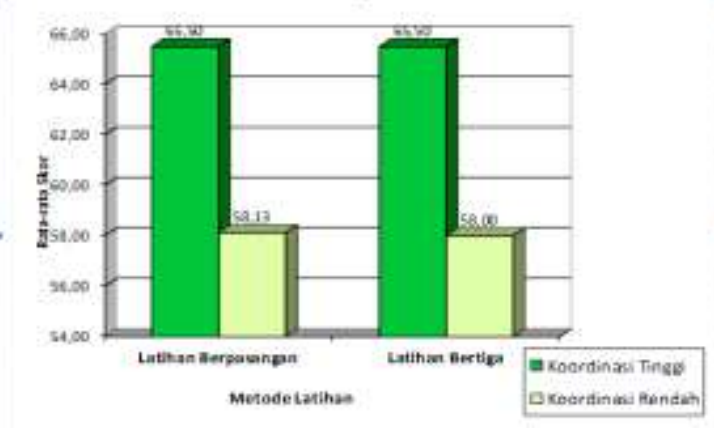

Gambar 1. Histogram Pencapaian Rata-rata Skor Keterampilan Awal Sepaksila pada Masing-masing Kelompok Perlakuan 
Berdasarkan hasil analisis data dengan bantuan software komputer, diperoleh hasil analisis pada data tes awal keterampilan sepaksila pada atlet sepaktakraw pelajar DIY pada kelompok koordinasi tinggi metode latihan berpasangan $\left(\mathrm{A}_{1} \mathrm{~B}_{1}\right)$ didapatkan rerata (mean) sebesar 65,50; median $=67,00$ mode $=67$ dan standard deviasi sebesar $=1,195$. Adapun pada kelompok koordinasi tinggi metode latihan bertiga $\left(\mathrm{A}_{1} \mathrm{~B}_{2}\right)$ didapatkan rerata (mean) sebesar 65,50; median $=65,00$ mode $=65$ dan standard deviasi sebesar $=2,588$.

Pada kelompok koordinasi rendah metode latihan berpasangan $\left(\mathrm{A}_{2} \mathrm{~B}_{1}\right)$ didapatkan rerata (mean) sebesar 58,13; median $=59,00$ mode $=60$ dan standard deviasi sebesar $=3,271$ dan pada kelompok koordinasi rendah metode latihan bertiga $\left(\mathrm{A}_{2} \mathrm{~B}_{2}\right)$ didapatkan rerata (mean) sebesar 58,00; median $=59,00$ mode $=60$ dan standard deviasi sebesar $=3,286$.

\section{Hasil Tes Akhir (Posttest)}

Hasil tes akhir keterampilan sepaksila pada atlet sepaktakraw pelajar DIY pada masing-masing kelompok perlakuan, secara ringkas disajikan pada tabel berikut ini.

Tabel 4. Statistik Deskriptif Keterampilan Akhir Sepaksila pada Masing-masing Kelompok Perlakuan

\begin{tabular}{ccccc}
\hline \multirow{2}{*}{ Statistik } & $\begin{array}{c}\text { Kemampuan } \\
\text { Koordinasi } \\
\text { Tinggi } \\
\left(\mathbf{A}_{\mathbf{1}}\right)\end{array}$ & $\begin{array}{c}\text { Kemampuan } \\
\text { Koordinasi } \\
\text { Rendah } \\
\left(\mathbf{A}_{\mathbf{2}}\right)\end{array}$ \\
\cline { 2 - 5 } & $\mathbf{B}_{\mathbf{1}}$ & $\mathbf{B}_{\mathbf{2}}$ & $\mathbf{B}_{\mathbf{1}}$ & $\mathbf{B}_{\mathbf{2}}$ \\
\hline Rerata (Mean) & 74,75 & 73,67 & 70,50 & 63,50 \\
Median & 75,50 & 74,00 & 71,00 & 63,50 \\
Mode & 76 & 74 & 70 & 60 \\
Standard & 4,097 & 2,066 & 3,854 & 2,739 \\
Deviasi & & & & \\
Variance & 16,786 & 4,267 & 14,857 & 7,500 \\
Range & 12 & 6 & 11 & 7 \\
Minimum & 68 & 70 & 64 & 60 \\
Maksimum & 80 & 76 & 75 & 67 \\
\hline
\end{tabular}

Berdasarkan tabel tersebut di atas, dapat dibuat histogram pencapaian rata-rata skor tes kemampuan akhir sepaksila pada atlet sepaktakraw pelajar DIY sebagai berikut:

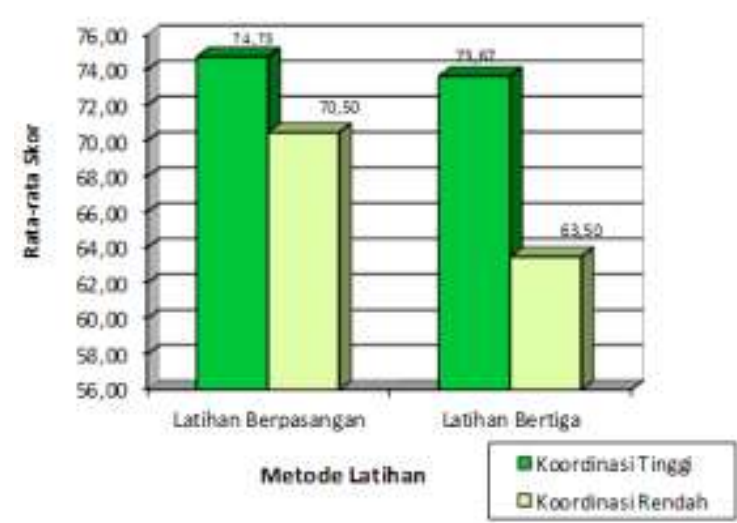

Gambar 2. Histogram Pencapaian Rata-rata

Skor Keterampilan Akhir Sepaksila pada Masing-masing Kelompok Perlakuan

Berdasarkan hasil analisis deskriptif seperti terlihat pada tabel dan gambar tersebut di atas, diperoleh hasil analisis pada data tes akhir keterampilan sepaksila pada atlet sepaktakraw pelajar DIY pada kelompok koordinasi tinggi metode latihan berpasangan $\left(\mathrm{A}_{1} \mathrm{~B}_{1}\right)$ didapatkan rerata (mean) sebesar 74,75; median $=75,00$ mode $=76$ dan standard deviasi sebesar $=$ 4,097 .

Adapun pada kelompok koordinasi tinggi metode latihan bertiga $\left(\mathrm{A}_{1} \mathrm{~B}_{2}\right)$ didapatkan rerata (mean) sebesar 73,67; median = 74,00 mode $=74$ dan standard deviasi sebesar $=$ 2,066. Pada kelompok koordinasi rendah metode latihan berpasangan $\left(\mathrm{A}_{2} \mathrm{~B}_{1}\right)$ didapatkan rerata (mean) sebesar 70,50; median $=71,00$ mode $=70$ dan standard deviasi sebesar $=3,854$ dan pada kelompok koordinasi rendah metode latihan bertiga $\left(\mathrm{A}_{2} \mathrm{~B}_{2}\right)$ didapatkan rerata (mean) sebesar 63,50; median $=63,00$ mode $=60$ dan standard deviasi sebesar $=2,739$.

Hasil Peningkatan Skor (Efektivitas Peningkatan)

Hasil peningkatan skor (gain score) antara tes awal dengan tes akhir keterampilan sepaksila pada atlet sepaktakraw pelajar DIY pada penelitian ini merupakan efektivitas dari metode latihan yang diberikan pada masingmasing kelompok, sehingga skor peningkatan ini dinyatakan dalam persentase (\%). Perolehan efektivitas ini adalah dari skor akhir dikurangi skor awal, dibagi dengan skor awal, kemudian dikalikan 100. Dapat dirumuskan, Peningkatan $=\{($ skor akhir - skor awal $) /$ skor awal $\} \times 100$. Hasil analisis data pada masing-masing kelompok perlakuan, secara ringkas disajikan pada tabel berikut ini. 
Tabel 5. Statistik Deskriptif Peningkatan (\%) Keterampilan Sepaksila pada Masing-masing Kelompok Perlakuan

\begin{tabular}{|c|c|c|c|c|}
\hline \multirow[t]{2}{*}{ Statistik } & \multicolumn{2}{|c|}{$\begin{array}{c}\text { Kemampuan } \\
\text { Koordinasi } \\
\text { Tinggi } \\
\left(\mathbf{A}_{1}\right) \\
\end{array}$} & \multicolumn{2}{|c|}{$\begin{array}{c}\text { Kemampuan } \\
\text { Koordinasi } \\
\text { Rendah } \\
\left(\mathbf{A}_{2}\right) \\
\end{array}$} \\
\hline & $\mathbf{B}_{1}$ & $\mathbf{B}_{2}$ & $\mathbf{B}_{1}$ & $\mathbf{B}_{2}$ \\
\hline $\begin{array}{l}\text { Rerata } \\
\text { (Mean) }\end{array}$ & 12,38 & 12,58 & 21,38 & 9,63 \\
\hline Median & 13,43 & 13,38 & 20,86 & 9,35 \\
\hline Mode & 14,43 & 7,25 & 14,75 & 4,92 \\
\hline $\begin{array}{c}\text { Standard } \\
\text { Deviasi }\end{array}$ & 5,194 & 4,417 & 4,790 & 4,582 \\
\hline Variance & 26,979 & 19,513 & 22,946 & 20,993 \\
\hline Range & 15,22 & 9,94 & 15,07 & 10,46 \\
\hline Minimum & 4,48 & 7,25 & 14,75 & 4,92 \\
\hline Maksimum & 19,70 & 17,19 & 29,82 & 15,38 \\
\hline
\end{tabular}

Berdasarkan tabel tersebut di atas, dapat dibuat histogram pencapaian rata-rata peningkatan (\%) skor tes kemampuan akhir sepaksila pada atlet sepaktakraw pelajar DIY sebagai berikut:

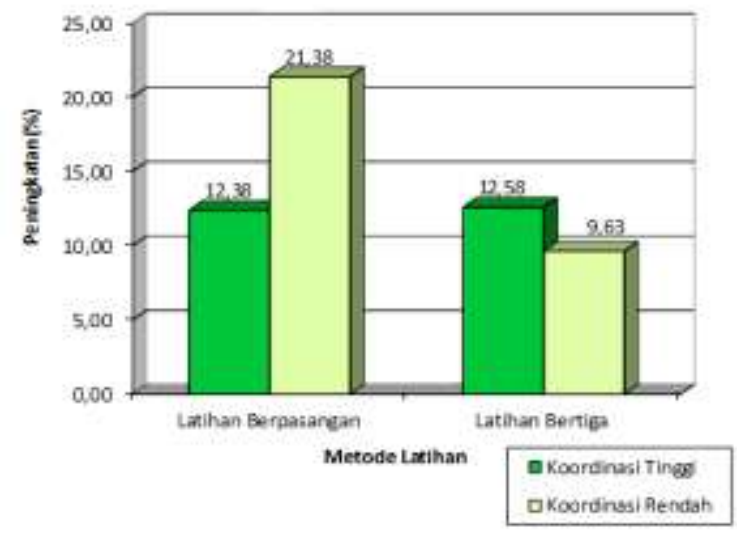

Gambar 3. Histogram Peningkatan (\%) Skor Keterampilan Akhir Sepaksila pada Masingmasing Kelompok Perlakuan

Berdasarkan hasil analisis deskriptif seperti terlihat pada tabel dan gambar tersebut di atas, diperoleh hasil analisis pada data peningkatan keterampilan sepaksila pada atlet sepaktakraw pelajar DIY pada kelompok koordinasi tinggi metode latihan berpasangan $\left(\mathrm{A}_{1} \mathrm{~B}_{1}\right)$ didapatkan rerata (mean) sebesar 12,38 ; median $=$ 13,43 mode $=14,43$ dan standard deviasi sebesar $=5,194$.

Adapun pada kelompok koordinasi tinggi metode latihan bertiga $\left(\mathrm{A}_{1} \mathrm{~B}_{2}\right)$ didapatkan rerata (mean) sebesar 12,58; median = 13,38 mode $=7,25$ dan standard deviasi sebesar $=4,417$. Pada kelompok koordinasi rendah metode latihan berpasangan $\left(\mathrm{A}_{2} \mathrm{~B}_{1}\right)$ dida- patkan rerata (mean) sebesar 21,38; median $=$ 20,86 mode $=14,75$ dan standard deviasi sebesar $=4,790$ dan pada kelompok koordinasi rendah metode latihan bertiga $\left(\mathrm{A}_{2} \mathrm{~B}_{2}\right)$ didapatkan rerata (mean) sebesar 9,63; median $=9,35$ mode $=4,93$ dan standard deviasi sebesar $=$ 4,583 .

Pengujian hipotesis pada penelitian ini digunakan anava dua jalur (Two-way Anova) dilanjutkan dengan uji-t antarkelompok (independent t-test). Prasyarat yang harus dipenuhi sebelum melakukan uji t dan anava tersebut adalah: (1) distribusi data normal yang diuji dengan uji normalitas sebaran; dan (2) variansi antar masing-masing kelompok homogen yang diuji dengan uji homogenitas variansi.

\section{Uji Normalitas Sebaran}

Uji normalitas sebaran data pada penelitian ini dipergunakan Kolmogorov-Smirnov Test dan dilakukan dengan bantuan software komputer, dalam hal ini SPSS. Hasil uji normalitas sebaran data secara ringkas disajikan pada tabel berikut ini.

Tabel 6. Hasil Uji Normalitas Sebaran

\begin{tabular}{lccc}
\hline \multirow{2}{*}{$\begin{array}{l}\text { Distriusi Data } \\
\text { Variabel }\end{array}$} & \multicolumn{2}{c}{$\begin{array}{c}\text { Kolmogorov- } \\
\text { Smirnov Test }\end{array}$} & \multirow{2}{*}{ Ket } \\
\cline { 2 - 3 } & Statistik & Sig. (p) & \\
\hline $\begin{array}{l}\text { Keterampilan } \\
\text { Sepaksila Awal }\end{array}$ & 0,644 & 0,801 & Normal \\
$\begin{array}{l}\text { Keterampilan } \\
\text { Sepaksila Akhir }\end{array}$ & 0,810 & 0,529 & Normal \\
$\begin{array}{l}\text { Peningkatan } \\
\begin{array}{l}\text { Keterampilan } \\
\text { Sepaksila }\end{array}\end{array}$ & 0,593 & 0,873 & Normal \\
\hline
\end{tabular}

Tabel tersebut di atas memperlihatkan bahwa, uji normalitas pada keterampilan sepaksila awal (pretest) didapatkan Kolmogorov-Smirnov (KS) sebesar 0,644 dengan p>0,05; pada data keterampilan sepaksila akhir (post-test) dihasilkan KS sebesar 0,810 dengan p $>0,05$; pada data peningkatan keterampilan sepaksila dihasilkan KS sebesar 0,593 dengan $\mathrm{p}>0,05$. Hasil tersebut menunjukkan semuanya dengan $\mathrm{p}>0,05$ yang berarti data-data tersebut berdistribusi normal artinya statistik parametrik telah terpenuhi. Dengan demikian maka uji normalitas sebaran telah terpenuhi semua, dan selanjutnya dapat dilakukan uji homogenitas varians.

\section{Uji Homogenitas Varians}

Pengujian homogenitas varians dimaksudkan untuk mengetahui apakah sampel yang 
diambil dari populasi berasal dari varians yang sama dan tidak menunjukkan perbedaan yang signifikan satu sama lain. Tes statistik yang digunakan pada penelitian ini adalah uji $\mathrm{F}$
(Levene's Test for Equality of Variances). Hasil analisis secara ringkas disajikan pada tabel berikut ini.

Tabel 7. Hasil Uji Homogenitas Varians Antarkelompok

\begin{tabular}{clccc}
\hline \multirow{2}{*}{ Antar Kelompok } & \multicolumn{1}{c}{ Data } & Levene's Test for Equality or Variances & \multirow{2}{*}{ Kesimp } \\
\cline { 3 - 4 } & & $\mathbf{F}$ & $\mathbf{p}$ (sig.) & \\
\hline \multirow{2}{*}{ Antar A (Kemampuan Koordinasi) } & Tes Awal & 3,201 & 0,085 & Homogen \\
& Tes Akhir & 4,130 & 0,052 & Homogen \\
& Peningkatan & 2,705 & 0,112 & Homogen \\
& Tes Awal & 0,198 & 0,660 & Homogen \\
Antar B (Metode Latihan) & Tes Akhir & 2,782 & 0,107 & Homogen \\
& Peningkatan & 1,021 & 0,321 & Homogen \\
Antar AB (Koordinasi \& Metode & Tes Awal & 2,023 & 0,137 & Homogen \\
Latihan & Tes Akhir & 1,026 & 0,399 & Homogen \\
& Peningkatan & 0,093 & 0,963 & Homogen \\
\hline
\end{tabular}

Berdasarkan tabel hasil uji homogenitas tersebut di atas, diketahui bahwa semua $\mathrm{F}_{\text {hitung }}$ menunjukkan tidak signifikan pada taraf signifikansi 5\%; hal ini ditunjukkan dengan $\mathrm{p}>0,05$. Karena $\mathrm{p}>0,05$ maka disimpulkan tidak ada perbedaan antara varians semua data (data tes awal, data tes akhir, dan data peningkatan), baik antar A (antarkemampuan koordinasi), antar B (antar perlakuan), dan antar-AB (antarkoordinasi dan perlakuan) menunjukkan bahwa data-data tersebut memenuhi syarat homogenitas varians artinya statistik parametrik homogen atau mempunyai kesamaan. Dengan demikian maka uji prasyarat analisis telah terpenuhi semua, dan selanjutnya dapat dilakukan pengujian hipotesis.

Dari kedua pengujian persyaratan, seperti telah dibahas di atas, semua persyaratan analisis, yaitu: data berdistribusi normal dan variansi antarkelompok homogen, telah terpenuhi, maka dapat dilanjutkan dengan analisis statistik parametrik varians dua jalur (two-way anova) dan uji-t antar kelompok (independent $t$ test).
Pengujian Hipotesis

Hipotesis yang diuji pada penelitian ini adalah: (1) Ada perbedaan keterampilan sepaksila ditinjau metode latihan (metode latihan berpasangan dengan metode latihan bertiga) pada atlet sepaktakraw pelajar DIY; (2) Ada perbedaan keterampilan sepaksila ditinjau kemampuan koordinasi (koordinasi tinggi dengan koordinasi rendah) pada atlet sepaktakraw pelajar DIY; (3) ada interaksi antara kemampuan koordinasi dan metode latihan terhadap keterampilan sepaksila pada atlet sepaktakraw pelajar DIY.

\section{Pengujian Hipotesis Penelitian dengan ANOVA Dua Jalur}

Hipotesis di uji dengan analisis statistik parametrik berupa analisis varians dua jalur (two-way anova). Data yang dianalisis adalah data keterampilan sepaksila akhir dan peningkatan keterampilan sepaksila. Sebelum dianalisis dengan anava dua jalur, berikut disajikan ringkasan hasil analisis statistik deskriptif pada masing-masing kelompok.

Tabel 8. Ringkasan Statistik Deskriptif pada Masing-masing Kelompok Koordinasi dan Metode Latihan (Perlakuan)

\begin{tabular}{ccccc}
\hline $\begin{array}{c}\text { Kemampuan } \\
\text { Koordinasi }\end{array}$ & Metode Latihan & n & Tes Akhir (Posttest) & Peningkatan (\%) \\
\hline \multirow{2}{*}{ Tinggi } & Berpasangan & 8 & 74,75 & 12,38 \\
& Bertiga & 6 & 73,67 & 12,58 \\
& Total & 14 & 74,29 & 12,46 \\
Rendah & Berpasangan & 8 & 70,50 & 21,38 \\
& Bertiga & 6 & 63,50 & 9,63 \\
& Total & 14 & 67,50 & 16,34 \\
\multirow{2}{*}{ Total } & Berpasangan & 16 & 72,63 & 16,88 \\
& Bertiga & 12 & 68,58 & 11,10 \\
& Total & 28 & 70,89 & 14,40 \\
\hline
\end{tabular}


Hasil anava dua jalur (two-way anova) pada data keterampilan sepaksila akhir (setelah perlakuan) pada atlet sepaktakraw pelajar DIY, disajikan pada tabel berikut ini.

Tabel 9 Ringkasan Anova Dua Jalur pada Data Keterampilan Sepaksila Akhir (Setelah Perlakuan) pada Atlet Sepaktakraw Pelajar DIY

\begin{tabular}{ccccccc}
\hline & \multirow{2}{*}{ Sumber } & \multicolumn{4}{c}{ Experimental Method } \\
\cline { 3 - 7 } Main Effects & Sum of Square & df & Mean Square & F & Sig.(p) \\
& Koordinasi (A) & 434,333 & 2 & 217,167 & 18,592 & $\left.0,000^{*}\right)$ \\
& Perlakuan (B) & $\mathbf{3 2 2 , 3 2 1}$ & $\mathbf{1}$ & $\mathbf{3 2 2 , 3 2 1}$ & $\mathbf{2 7 , 5 9 5}$ & $\mathbf{0 , 0 0 0}$ \\
2-Way Interactions & $\mathbf{1 1 2 , 0 1 2}$ & $\mathbf{1}$ & $\mathbf{1 1 2 , 0 1 2}$ & $\mathbf{9 , 5 9 0}$ & $\left.\mathbf{0 , 0 0 5}^{*}\right)$ \\
& Koordinasi * Perlakuan (AB) & $\mathbf{6 0 , 0 1 2}$ & $\mathbf{1}$ & $\mathbf{6 0 , 0 1 2}$ & $\mathbf{5 , 1 3 8}$ & $\left.\mathbf{0 , 0 3 3}^{*}\right)$ \\
& Model & 494,345 & 3 & 464,782 & 14,107 & $\left.0,000^{*}\right)$ \\
& Residual & 280,333 & 24 & 11,681 & -- & -- \\
& Total & 774,679 & 27 & 28,692 & -- & -- \\
\hline
\end{tabular}

Keterangan:

${ }^{*}=$ Signifikan pada taraf signifikansi $5 \%$.

Adapun hasil Anava Dua Jalur (two-way anova) pada data peningkatan (\%) keterampilan sepaksila pada atlet sepaktakraw pelajar DIY, disajikan pada tabel berikut ini.

Tabel 10. Ringkasan Anava Dua Jalur pada Data Peningkatan Keterampilan Sepaksila pada Atlet Sepaktakraw Pelajar DIY

\begin{tabular}{ccccccc}
\hline & \multirow{2}{*}{ Sumber } & \multicolumn{4}{c}{ Experimental Method } \\
\cline { 3 - 7 } & & Sum of Square & df & $\begin{array}{c}\text { Mean } \\
\text { Square }\end{array}$ & F & Sig. (p) \\
\hline Main Effects & Koordinasi (A) & 334,192 & $\mathbf{1}$ & 167,096 & 7,265 & $\left.0,000^{*}\right)$ \\
& Perlakuan (B) & $\mathbf{1 0 5 , 4 2 0}$ & $\mathbf{1}$ & $\mathbf{1 0 5 , 4 2 0}$ & $\mathbf{4 , 5 8 3}$ & $\mathbf{0 , 0 4 3}^{*}$ \\
\multirow{4}{*}{ 2-Way Interactions } & $\mathbf{2 2 8 , 7 7 3}$ & $\mathbf{1}$ & $\mathbf{2 2 8 , 7 7 3}$ & $\mathbf{9 , 9 4 7}$ & $\left.\mathbf{0 , 0 0 5}^{*}\right)$ \\
& Koordinasi * Perlakuan (AB) & $\mathbf{2 4 4 , 7 1 9}$ & 3 & $\mathbf{2 4 4 , 7 1 9}$ & $\mathbf{1 0 , 6 4 0}$ & $\left.\mathbf{0 , 0 0 3}^{*}\right)$ \\
& Model & 578,911 & 24 & 192,970 & 8,390 & $\left.0,001^{*}\right)$ \\
& Residual & 552,007 & 27 & 23,000 & -- & - \\
& Total & 1130,918 & $\mathbf{1}$ & $\mathbf{4 1 , 8 8 6}$ & -- & -- \\
\hline
\end{tabular}

Keterangan:

*) = Signifikan pada taraf signifikansi 5\%

\section{Pengujian Hipotesis Pertama}

Hipotesis pertama pada penelitian ini berbunyi: "Ada perbedaan keterampilan sepaksila ditinjau metode latihan (metode latihan berpasangan dengan metode latihan bertiga) pada atlet sepaktakraw pelajar DIY". Hipotesis tersebut diuji menggunakan teknik analisis statistik parametrik, yaitu Anava Dua Jalur. Berdasarkan hasil analisis pada data keterampilan sepaksila akhir (sesudah perlakuan) diperoleh $\mathrm{F}_{\text {hitung }}$ antarmetode latihan (Antar B) sebesar 9,590 dengan signifikansi atau $\mathrm{p}=0,005$; sehingga uji hipotesis diterima.

\section{Pengujian Hipotesis Kedua}

Hipotesis kedua pada penelitian yang berbunyi: "Ada perbedaan keterampilan sepaksila ditinjau kemampuan koordinasi (koordinasi tinggi dengan koordinasi rendah) pada atlet sepaktakraw pelajar DIY". Hipotesis tersebut diuji menggunakan teknik analisis statistik parametrik, yaitu Anava Dua Jalur. Berdasarkan hasil analisis pada data keterampilan sepaksila akhir (sesudah perlakuan) diperoleh $\mathrm{F}_{\text {hitung }}$ antar kemampuan koordinasi (Antar A) sebesar 27,595 dengan signifikansi atau $\mathrm{p}=0,000$; sehingga uji hipotesis diterima.

\section{Pengujian Hipotesis Ketiga}

Hipotesis ketiga pada penelitian yang berbunyi; "Ada interaksi antara metode latihan dan kemampuan koordinasi terhadap keterampilan sepaksila pada atlet sepaktakraw pelajar DIY". Hipotesis tersebut diuji menggunakan teknik analisis statistik parametrik, yaitu Anava Dua Jalur. Berdasarkan hasil analisis pada data keterampilan sepaksila akhir (sesudah perlakuan) diperoleh $\mathrm{F}_{\text {hitung }}$ 2-Way Interaction (Interaksi AB) sebesar 5,138 dengan signifikansi atau $p=0,033$. Ternyata $p$ kurang dari taraf signifikansi yang ditentukan yaitu $5 \%$ atau $\mathrm{p}<0,05$; maka uji hipotesis diterima yang menyatakan ada interaksi yang signifikan antara kemampuan koordinasi dan metode latihan ter- 
hadap keterampilan sepaksila pada atlet sepaktakraw pelajar DIY.

Artinya hipotesis diterima yang menyatakan ada interaksi yang signifikan antara metode latihan dan kemampuan koordinasi terhadap keterampilan sepaksila pada atlet sepaktakraw pelajar DIY.

\section{Uji Lanjutan Menggunakan Uji Tukey}

Setelah dilakukan uji varians maka perlu dilakukan pengujian perbedaan per pasangan dengan uji Tukey untuk menentukan pasangan yang berbeda secara signifikan dan pasangan yang tidak berbeda. Sebelum dilakukan analisis perbedaan antara masing-masing kelompok perlakuan, sebelumnya dianalisis lebih lanjut agar mendapatkan gambaran perolehan rerata skor, yaitu rerata skor keterampilan sepaksila akhir dan rerata peningkatan keterampilan sepaksila, berikut disajikan histogram rerata tersebut.

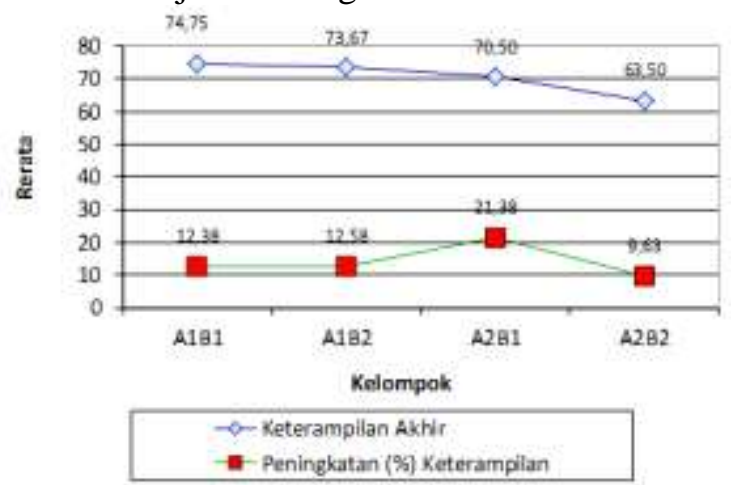

Gambar 4. Rerata Keterampilan Sepaksila Akhir dan Peningkatan Keterampilan Sepaksila pada Masing-masing Kelompok

Keterangan:

$\mathrm{A}_{1} \mathrm{~B}_{1}$ : Kemampuan Koordinasi Tinggi \& Latihan Berpasangan

$\mathrm{A}_{1} \mathrm{~B}_{2}$ : Kemampuan Koordinasi Tinggi \& Latihan Bertiga

$\mathrm{A}_{2} \mathrm{~B}_{1}$ : Kemampuan Koordinasi Rendah \& Latihan Berpasangan

$\mathrm{A}_{2} \mathrm{~B}_{2}$ : Kemampuan Koordinasi Rendah \& Latihan Bertiga

Histogram tersebut di atas memperlihatkan bahwa, perolehan skor keterampilan sepaksila pada atlet sepaktakraw pelajar DIY paling tinggi adalah pada kelompok $\mathrm{A}_{1} \mathrm{~B}_{1}$ (kemampuan koordinasi tinggi dan latihan berpasangan) dengan rerata skor 74,75 ; disusul kelompok $\mathrm{A}_{1} \mathrm{~B}_{2}$ (kemampuan koordinasi tinggi dan latihan bertiga) dengan rerata skor 73,67; selanjutnya kelompok $\mathrm{A}_{2} \mathrm{~B}_{1}$ (kemampuan koordinasi rendah dan latihan berpasangan) dengan rerata skor 70,50; dan kelompok $\mathrm{A}_{2} \mathrm{~B}_{2}$ (kemam- puan koordinasi rendah dan latihan berpasangan) dengan rerata skor 63,50 .

Apabila dilihat dari peningkatan keterampilan sepaksila atau efektivitas peningkatannya pada atlet sepaktakraw pelajar DIY adalah pada kelompok $\mathrm{A}_{2} \mathrm{~B}_{1}$ (kemampuan koordinasi rendah dan latihan berpasangan) dengan rerata skor 21,38; disusul $\mathrm{A}_{1} \mathrm{~B}_{2}$ (kemampuan koordinasi tinggi dan latihan bertiga) dengan rerata skor 12,58 ; dan selanjutnya $\mathrm{A}_{1} \mathrm{~B}_{1}$ (kemampuan koordinasi tinggi dan latihan berpasangan) dengan rerata skor 12,38 ; serta $\mathrm{A}_{2} \mathrm{~B}_{2}$ (kemampuan koordinasi tinggi dan latihan berpasangan) dengan rerata skor 9,63.

Hasil ini membuktikan bahwa latihan berpasangan efektif pada atlet dengan kemampuan koordinasi rendah, sedangkan latihan bertiga efektif pada atlet dengan kemampuan koordinasi tinggi. Analisis perbedaan efektivitas peningkatan pada masing-masing kelompok, secara ringkas disajikan pada tabel berikut ini.

Tabel 11. Hasil Uji Lanjut, Analisis Perbeda-an dengan T-test Antar Kelompok (Independent Ttest)

\begin{tabular}{|c|c|c|c|}
\hline $\begin{array}{l}\text { Perbedaan } \\
\text { Antara: }\end{array}$ & $\mathbf{t}_{\text {hitung }}$ & $\begin{array}{l}\text { Sig. } \\
(\mathbf{p})\end{array}$ & Keterangan \\
\hline $\mathrm{A}_{1} \mathrm{~B}_{1}><\mathrm{A}_{1} \mathrm{~B}_{2}$ & $-0,075$ & 0,941 & $\begin{array}{c}\text { Tidak } \\
\text { Signifikan }\end{array}$ \\
\hline $\mathrm{A}_{1} \mathrm{~B}_{1}><\mathrm{A}_{2} \mathrm{~B}_{1}$ & $-3,603$ & 0,003 & Signifikan \\
\hline $\mathrm{A}_{1} \mathrm{~B}_{1}><\mathrm{A}_{2} \mathrm{~B}_{2}$ & 1,029 & 0,324 & $\begin{array}{c}\text { Tidak } \\
\text { Signifikan }\end{array}$ \\
\hline $\mathrm{A}_{1} \mathrm{~B}_{2}><\mathrm{A}_{2} \mathrm{~B}_{1}$ & $-3,514$ & 0,004 & Signifikan \\
\hline $\mathrm{A}_{1} \mathrm{~B}_{2}><\mathrm{A}_{2} \mathrm{~B}_{2}$ & 1,134 & 0,283 & $\begin{array}{c}\text { Tidak } \\
\text { Signifikan }\end{array}$ \\
\hline $\left.\mathrm{A}_{2} \mathrm{~B}_{1}\right\rangle\left\langle\mathrm{A}_{2} \mathrm{~B}_{2}\right.$ & 4,625 & 0,001 & Signifikan \\
\hline
\end{tabular}

Keterangan:

$\mathrm{A}_{1} \mathrm{~B}_{1}=$ Koordinasi Tinggi - Latihan Berpasangan

$\mathrm{A}_{1} \mathrm{~B}_{2}=$ Koordinasi Tinggi - Latihan Bertiga

$\mathrm{A}_{2} \mathrm{~B}_{1}=$ Koordinasi Rendah - Latihan Berpasangan

$\mathrm{A}_{2} \mathrm{~B}_{2}=$ Koordinasi Rendah - Latihan Bertiga

Berdasarkan hasil analisis seperti tersaji pada tabel di atas, dapat dideskripsikan sebagai berikut: (1) Perbedaan Efektivitas Peningkatan Keterampilan sepaksila antara Koordinasi Tinggi Latihan Berpasangan dengan Koordinasi Tinggi Latihan Bertiga $\left(\mathrm{A}_{1} \mathrm{~B}_{1}><\right.$ $A_{1} B_{2}$ ). Diperoleh $t_{\text {hitung }}$ sebesar $-0,075$ dengan $p=0,941$; karena $p>0,05$ maka dinyatakan bahwa tidak ada perbedaan yang signifikan efektifitas peningkatan keterampilan sepaksila antara atlet kemampuan koordinasi tinggi dan 
latihan berpasangan dengan atlet kemampuan koordinasi tinggi dan latihan bertiga pada atlet sepaktakraw pelajar DIY; (2) Perbedaan Efektivitas Peningkatan Keterampilan Sepaksila antara Koordinasi Tinggi Latihan Berpasangan dengan Koordinasi Rendah Latihan Berpasangan $\left(\mathrm{A}_{1} \mathrm{~B}_{1}><\mathrm{A}_{2} \mathrm{~B}_{1}\right)$. Diperoleh $\mathrm{t}_{\text {hitung }}$ sebesar 3,603 dengan $\mathrm{p}=0,003$; karena $\mathrm{p}<0,05$ maka dinyatakan bahwa ada perbedaan yang signifikan efektifitas peningkatan keterampilan sepaksila antara atlet kemampuan koordinasi tinggi dan latihan berpasangan dengan atlet kemampuan koordinasi rendah dan latihan berpasangan pada atlet sepaktakraw pelajar DIY. Atlet kemampuan koordinasi rendah dan latihan berpasangan lebih tinggi tingkat peningkatannya dibandingkan dengan atlet kemampuan koordinasi tinggi dan latihan berpasangan. Hal ini berarti latihan berpasangan pada atlet dengan koordinasi rendah lebih efektif dalam meningkatkan keterampilan sepaksila dibandingkan dengan atlet dengan koordinasi tinggi; (3) Perbedaan Efektivitas Peningkatan Keterampilan Sepaksila antara Koordinasi Tinggi Latihan Berpasangan dengan Koordinasi Rendah Latihan Bertiga $\left(\mathrm{A}_{1} \mathrm{~B}_{1}><\mathrm{A}_{2} \mathrm{~B}_{2}\right)$. Diperoleh $\mathrm{t}_{\text {hitung }}$ sebesar 1,029 dengan $p=0,324$; karena $p>0,05$ maka dinyatakan bahwa tidak ada perbedaan yang signifikan efektifitas peningkatan keterampilan sepaksila antara atlet kemampuan koordinasi tinggi dan latihan berpasangan dengan atlet kemampuan koordinasi rendah dan latihan bertiga pada atlet sepaktakraw pelajar DIY; (4) Perbedaan Efektivitas Peningkatan Keterampilan Sepaksila antara Koordinasi Tinggi Latihan Bertiga dengan Koordinasi Rendah Latihan Berpasangan $\left(\mathrm{A}_{1} \mathrm{~B}_{2}><\mathrm{A}_{2} \mathrm{~B}_{1}\right)$. Diperoleh $t_{\text {hitung }}$ sebesar $-3,514$ dengan $p=0,004$; karena $\mathrm{p}<0,05$ maka dinyatakan bahwa ada perbedaan yang signifikan efektifitas peningkatan keterampilan sepaksila antara atlet kemampuan koordinasi tinggi dan latihan bertiga dengan atlet kemampuan koordinasi rendah dan latihan berpasangan pada atlet sepaktakraw pelajar DIY. Atlet kemampuan koordinasi rendah dan latihan berpasangan lebih tinggi tingkat peningkatannya dibandingkan dengan atlet kemampuan koordinasi tinggi dan latihan bertiga; (5) Perbedaan Efektivitas Peningkatan Keterampilan Sepaksila antara Koordinasi Tinggi Latihan Bertiga dengan Koordinasi Rendah Latihan Bertiga $\left(A_{1} B_{2}><A_{2} B_{2}\right)$. Diperoleh $t_{\text {hitung }}$ sebesar 1,134 dengan $p=0,283$; karena $p>0,05$ maka dinyatakan bahwa tidak ada perbedaan yang signifikan efektifitas peningkatan keterampilan sepaksila antara atlet kemampuan koordinasi tinggi dan latihan bertiga dengan atlet kemampuan koordinasi rendah dan latihan bertiga pada atlet sepaktakraw pelajar DIY; (6) Perbedaan Efektivitas Peningkatan Keterampilan Sepaksila antara Koordinasi Rendah Latihan Berpasangan dengan Koordinasi Rendah Latihan Bertiga $\left(A_{2} B_{1}><A_{2} B_{2}\right)$. Diperoleh $t_{\text {hitung }}$ sebesar 4,625 dengan $p=0,004$; karena $p<0,05$ maka dinyatakan bahwa ada perbedaan yang signifikan efektifitas peningkatan keterampilan sepaksila antara atlet kemampuan koordinasi rendah dan latihan berpasangan dengan atlet kemampuan koordinasi rendah dan latihan bertiga pada atlet sepaktakraw pelajar DIY.

Hasil ini membuktikan bahwa pada atlet dengan kemampuan koordinasi yang rendah, lebih efektif dengan latihan berpasangan dibandingkan dengan latihan bertiga dalam peningkatan keterampilan sepaksila pada atlet sepaktakraw pelajar DIY.

\section{Pembahasan}

Pengaruh Metode Latihan Terhadap

Keterampilan Sepaksila

Penelitian ini membuktikan bahwa ada perbedaan yang signifikan $(\mathrm{p}<0,05)$ keterampilan sepaksila ditinjau metode latihan (antara metode latihan berpasangan dengan metode latihan bertiga) pada atlet sepaktakraw pelajar DIY. Hal ini dibuktikan dengan $F_{\text {hitung }}$ antarmetode latihan (Antar B) pada data keterampilan sepaksila akhir sebesar 9,590 dengan $\mathrm{p}<0,05$ dan diperkuat dengan $F_{\text {hitung }}$ antar A pada data peningkatan keterampilan sepaksila sebesar 9,947 dengan $\mathrm{p}<0,05$.

Berdasarkan pembahasan di atas dapat disimpulkan bahwa kedua metode latihan berpasangan dan latihan bertiga berpengaruh terhadap keterampilan sepaksila. Metode Latihan berpasangan dan metode latihan bertiga mempunyai kelebihan dan kekurangan sendiri-sendiri. Pelatih diharapkan jeli dalam memilih metode latihan yang sesuai dengan karakteristik dan kemampuan atlet.

\section{Pengaruh Koordinasi Terhadap Keterampilan Sepaksila}

Penelitian ini membuktikan bahwa ada perbedaan yang signifikan $(\mathrm{p}<0,05)$ keterampilan sepaksila ditinjau kemampuan koordinasi (antara kemampuan koordinasi tinggi dengan kemampuan koordinasi rendah) pada atlet sepaktakraw pelajar DIY. Hal ini dibuktikan de- 
ngan $\mathrm{F}_{\text {hitung }}$ antar kemampuan koordinasi (Antar A) pada data keterampilan sepaksila akhir sebesar 27,595 dengan $\mathrm{p}<0,05$ dan diperkuat dengan $\mathrm{F}_{\text {hitung }}$ antar A pada data peningkatan keterampilan sepaksila sebesar 4,583 dengan $\mathrm{p}<0,05$.

Berdasarkan pembahasan di atas maka dapat ditarik kesimpulan bahwa atlet dengan kemampuan koordinasi tinggi lebih efektif diberikan kepada yang level keterampilan tingkat lanjut dan untuk atlet pemula lebih efektif diberikan pada yang mempunyai koordinasi. interaksi antara metode latihan dan kemampuan koordinasi terhadap keterampilan sepaksila

Penelitian ini membuktikan bahwa ada interaksi yang signifikan $(\mathrm{p}<0,05)$ antara metode latihan dan kemampuan koordinasi terhadap keterampilan sepaksila pada atlet sepaktakraw pelajar DIY. Hal ini dibuktikan dengan $\mathrm{F}_{\text {hitung }} 2$ Way Interaction (Interaksi AB) pada data keterampilan sepaksila akhir sebesar 5,138 dengan $\mathrm{p}<0,05$ dan $\mathrm{F}_{\text {hitung }} 2$-Way Interaction (Interaksi AB) pada data peningkatan keterampilan sepaksila sebesar 10,640 dengan $\mathrm{p}<0,05$.

Efektivitas peningkatan keterampilan sepaksila pada atlet sepaktakraw pelajar DIY paling tinggi adalah pada kelompok $\mathrm{A}_{2} \mathrm{~B}_{1}$ dengan rerata skor 21,38; disusul $\mathrm{A}_{1} \mathrm{~B}_{2}$ dengan rerata skor 12,58; dan selanjutnya $A_{1} B_{1}$ dengan rerata skor 12,38; serta $A_{2} B_{2}$ dengan rerata skor 9,63. Hasil ini membuktikan bahwa latihan berpasangan efektif pada atlet dengan kemampuan koordinasi rendah, sedangkan latihan bertiga efektif pada atlet dengan kemampuan koordinasi tinggi.

\section{Simpulan dan Saran}

\section{Simpulan}

Penelitian ini menggunakan metode eksperimen yang melibatkan variabel bebas, yaitu model latihan dan kemampuan koordinasi, sedangkan variabel terikatnya adalah keterampilan sepaksila. Model latihan sebagai variabel bebas yang dimanipulasi dibagi menjadi dua, yaitu metode latihan berpasangan dan metode latihan bertiga. Kemampuan koordinasi sebagai variabel bebas yang dikendalikan (atribut) dibagi menjadi dua, yaitu kemampuan koordinasi tinggi dan kemampuan koordinasi rendah. Keterampilan sepaksila sebagai variabel terikat.

Berdasarkan hasil penelitian, pengujian hipotesis dan pembahasan, dapat disimpulkan beberapa hal berikut ini: (1) Ada perbedaan yang signifikan keterampilan sepaksila ditinjau metode latihan (antara metode latihan berpasangan dengan metode latihan bertiga) pada atlet sepaktakraw pelajar DIY; (2) Ada perbedaan yang signifikan keterampilan sepaksila ditinjau kemampuan koordinasi (antara kemampuan koordinasi tinggi dengan kemampuan koordinasi rendah) pada atlet sepaktakraw pelajar DIY; (3) Ada interaksi yang signifikan antara kemampuan koordinasi dan metode latihan terhadap keterampilan sepaksila pada atlet sepaktakraw pelajar DIY. Latihan berpasangan paling efektif pada atlet dengan kemampuan koordinasi rendah, sedangkan latihan bertiga paling efektif pada atlet dengan kemampuan koordinasi tinggi dalam meningkatan keterampilan sepaksila.

Saran

Dari hasil penelitian, pembahasan hasil penelitian, dan kesimpulan, disarankan beberapa hal untuk peningkatan hasil latihan dalam permainan sepaktakraw, terutama peningkatan keterampilan sepaksila sebagai berikut: (1) Metode latihan berpasangan dan bertiga efektif untuk peningkatan keterampilan sepaksila khususnya dan peningkatan keterampilan bermain sepaktakraw pada umumnya; (2) Saran kepada praktisi olahraga dalam hal ini guru dan pelatih olahraga agar dapat menyusun dan mengaplikasikan metode latihan berpasangan dan bertiga, serta menambah variasi latihan untuk meningkatkan keterampilan sepaksila dalam bermain sepaktakraw; (3) Pelatih dalam mengaplikasikan metode latihan yang diberikan perlu menyesuaikan dengan karakteristik dan kemampuan atlet; (4) Dibutuhkan kreativitas dan inovasi dalam menerapkan metode latihan yang akan diberikan kepada atlet agar terjadi progresivitas peningkatan keterampilan atlet dalam bermain sepaktakraw; (5) Saran kepada para pakar, peneliti dan steakholder olahraga perlu menambah kualitas sepaktakraw seperti: pembuatan buku dan jurnal-jurnal penelitian agar mempermudah bagi para pembaca maupun para peneliti dalam mencari literatur tentang sepaksila dan secara umum mengenai sepaktakraw.

\section{Daftar Pustaka}

Darwis, Ratinus. (1991). Olahraga pilihan sepaktakraw. Jakarta:

Depdikbud. (2004). Peraturan permainan sepaktakraw. Jakarta: Depdiknas. 
Harsuki. (2012). Pengantar menajemen olahraga, Jakarta: PT Rajagrafindo Persada.

Sugiyono. 2011. Metode Penelitian Kuantitatif, Kualitatif, dan $R \& D$. Bandung: AFABETA

Sukadiyanto. (2004). Keterampilan groundstrokes tennis: Model pembelajaran terbuka dan tertutup. Disertasi doktor, tidak diterbitkan, Universitas Negeri Jakarta, Jakarta.
Thamrin, Husni. (2006). Tingkat keterampilan bermain sepaktakraw. Laporan Penelitian Fakultas Ilmu Keolahragaan Universitas Negeri Yogyakarta.

Yusuf, Ucup, dkk. (2001). Pembelajaran permainan sepaktakraw. Jakarta: Depdiknas 